\title{
Hunter-gatherers, biogeographic barriers and the development of human settlement in Tierra del Fuego
}

Flavia Morello ${ }^{1}$, Luis Borrero ${ }^{2}$, Mauricio Massone ${ }^{3}$, Charles Stern ${ }^{4}$, Arleen García-Herbst ${ }^{5}$, Robert McCulloch ${ }^{6}$, Manuel Arroyo-Kalin ${ }^{7}$, Elisa Calás ${ }^{8}$, Jimena Torres ${ }^{9}$, Alfredo Prieto ${ }^{1}$, Ismael Martinez ${ }^{8}$, Gabriel Bahamonde ${ }^{1} \&$ Pedro Cárdenas ${ }^{1}$

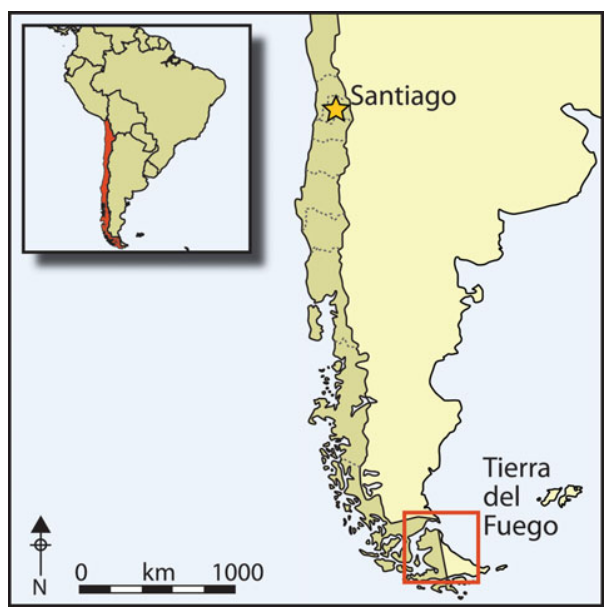

Tierra del Fuego represents the southernmost limit of human settlement in the Americas. While people may have started to arrive there around $10500 \mathrm{BP}$, when it was still connected to the mainland, the main wave of occupation occurred 5000 years later, by which time it had become an island. The co-existence in the area of maritime huntergatherers (in canoes) with previous terrestrial occupants pre-echoes the culturally distinctive groups encountered by the first European visitors in the sixteenth century. The study also provides a striking example of interaction across challenging natural barriers.

Keywords: Patagonia, Tierra del Fuego, Holocene, human dispersal, hunter-gatherers, barriers, interactions, canoes

1 Universidad de Magallanes, Instituto de la Patagonia, Centro de Estudios del Hombre Austral, Av. Bulnes 01890,Punta Arenas, CP 6200000,Chile(Email:flavia.morello@umag.cl; alfredo.prieto@umag.cl; gabriel.bahamonde@umag.cl; pedro.cardenas@umag.cl)

2 DIPA, IMIHICIHU, CONICET, Saavedra 15, Piso 5, Buenos Aires, C1083ACA, Argentina (Email: laborrero@hotmail.com)

3 Museo de Historia Natural de Concepción, DIBAM, Maipú 2359, Concepción, 4050014, Chile (Email: mmassone@surnet.cl)

4 Department of Geological Sciences, University of Colorado, UCB 399, Boulder, CO 80309-0399, USA (Email: charles.stern@colorado.edu)

5 Department of Anthropology, University of California, Santa Barbara, CA 93106-3210, USA; ASM Affiliates, 2034 Corte Del Nogal, Carlsbad, CA 92011, USA (Email: agarciaherbst@gmail.com)

6 Biological \& Environmental Sciences, School of Natural Sciences, University of Stirling, Stirling FK9 4LA, UK (Email:robert.mcculloch@stir.ac.uk)

7 Institute of Archaeology, University College London, 31-34 Gordon Square, London WC1H OPY; Department of Archaeology, Durham University, South Road, Durham DH1 3LE, UK (Email: manuelarroyokalin@gmail.com)

8 Arqueóloga, Facultad de Ciencias Sociales de la Universidad de Chile, Av. Ignacio Carrera Pinto 1045 Nuñoa, Santiago 8320000,Chile (Email: elisa.calas@gmail.com; ismart68@gmail.com)

$9 \quad$ Université de Paris I Panthéon-Sorbonne, 14 rue du Roi de Sicile, Paris 75004, France (Email: jimenatorres77@gmail.com)

(C) Antiquity Publications Ltd. ANTIQUITY 86 (2012): 71-87 


\section{Introduction}

The archaeology of sea barriers comprises a variety of situations, many of which concern the colonisation of oceanic islands (Cherry 1981) or particularly difficult crossings like the Strait of Gibraltar (Derricourt 2005). In contrast, Tierra del Fuego $\left(52^{\circ}-55^{\circ} \mathrm{S}\right.$ ), located in southernmost South America, was intermittently joined to the Patagonian mainland until c. $8000 \mathrm{BP}$, when it became an island. The significance of Tierra del Fuego for global archaeology lies both in being the southern limit of human dispersal in the Americas, and in having been home to culturally distinct terrestrial and maritime hunter-gatherer groups that persisted until the twentieth century AD. In this paper we summarise extant knowledge about the earliest human occupation of the island and discuss existing and new evidence for long-distance interaction during its subsequent human occupation.

\section{Island Tierra del Fuego}

After the Last Glacial Maximum (c. 25 000-23 000 BP) glaciers re-advanced on two occasions, generating windows of opportunity for early people to migrate from Patagonia to Tierra del Fuego (McCulloch \& Morello 2009). After c. 10315 BP, Early Holocene warming led to the rapid retreat of the Patagonian ice fields but global sea levels continued to be approximately $20-60 \mathrm{~m}$ below present-day sea levels, forming a land bridge across what today is an inter-oceanic passage, the Strait of Magellan. This situation persisted until the start of marine incursion, at c. 8300-7500 BP (McCulloch et al. 2005).

The main island of Tierra del Fuego, Isla Grande de Tierra del Fuego, today is over $250 \mathrm{~km}$ long and $400 \mathrm{~km}$ wide (Figure 1). The north-central zone is dominated by plains and rolling hills and the southern part is shaped by the Darwin Cordillera, an extension of the Andean range. A mean annual temperature of $5^{\circ} \mathrm{C}$ and rainfall of around $400 \mathrm{~mm}$ per year reflect the influence of the Westerlies (Pisano 1977). Among the noteworthy Holocene fauna are guanaco (Lama guanicoe), fox (Dusicyon culpaeus) and rodents, in particular coruro (Ctenomys sp). The low density of terrestrial mammals is supplemented by permanent and seasonal marine and terrestrial birds, e.g. caiquen (Chloephaga picta), albatros (Diomedea melanophris) and penguin (Aptenodytes patagonicus, Spheniscus magellanicus), as well as by marine mammals such as sea lions (Otaria flavescens and Arctocephalus australis) and cetaceans, along with fish and mollusks. Broadly speaking, the northern half of the island is dominated by open vegetation while the southern half is characterised by southern beech forest.

\section{The view from ethnography}

Nomadic hunter-gatherers were observed inhabiting the region from the first European sighting of the Strait of Magellan in 1520. Ethnographic accounts record two distinct groups in Tierra del Fuego and mainland Patagonia: maritime hunter-gatherers (Alacalufe/ Kaweskar and Yamana/Yagan) were skilled navigators who relied on bark canoes but rarely ventured far inland (their archaeological record of shell middens first appears in the region around 6500 BP (Legoupil \& Fontugne 1997). Terrestrial hunter-gatherers (Tehuelches/Aónikenk and Selk'nam/Ona in Tierra del Fuego) were averse to using vessels

(C) Antiquity Publications Ltd. 


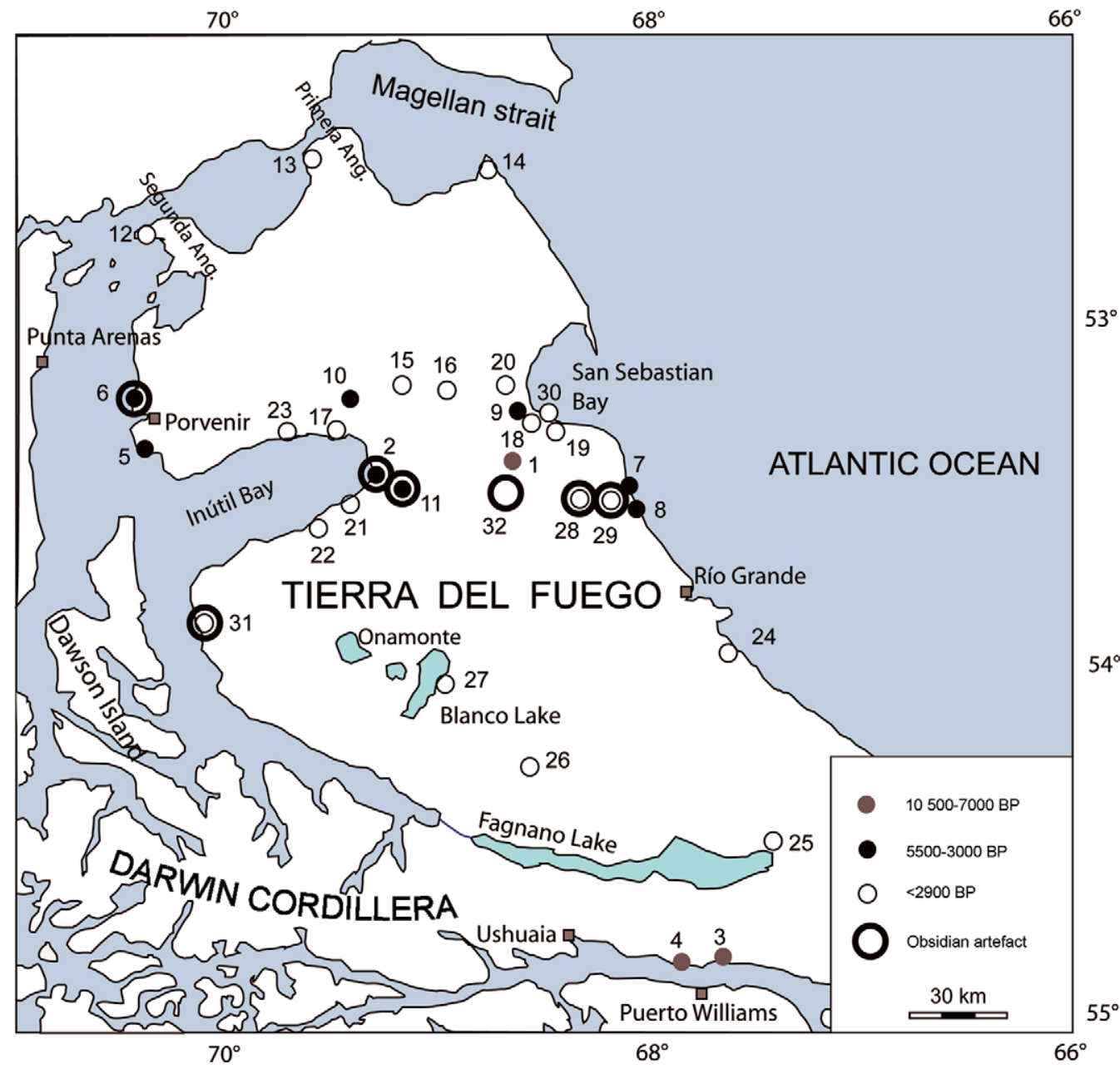

Figure 1. Isla Grande de Tierra del Fuego with Holocene archaeological sites and location of obsidian artefacts: 1) Tres Arroyos 1, 7 and 14/ Cerro de los Onas; 2) Marazzi 1, 32 and 38; 3) Imiwaia 1; 4) Túnel 1; 5) Cabo Monmouth 20 and 5; 6) Porvenir Norte 12E, 17 and 19; 7) Laguna Arcillosa 1, 2 and 3; 8) Río Chico 1; 9) Cerro Las Bandurrias, Cerro 'Sin Nombre' and Cerro de los Gatos; 10) Myrén 2; 11) Marazzi 13; 12) Cabo San Vicente; 13) Punta Baxa 7; 14) Punta Catalina 3, 4 and Espiritu Santo 1; 15) Lago Vergara E23, E24; 16) Laguna Larga F1, F4; 17) Riachuelo Puesto Nuevo; 18) Cabeza de León/Bloque Errático; 19) San Genaro; 20) LA11 and LA12; 21) Marazzi 2-Río Torcido; 22) La Ballena 2, Taca Taca Sur, Bloque El Maucho and Bloque El Hediondo; 23) Bahía Inútil 27; 24) Punta María 2; 25) Fagnano 1; 26) Marina 1; 27) Lago Blanco 1; 28) Las Vueltas 1 and Laguna Grande; 29) Áviles 1, 3 and Amalia 4; 30) Puesto Pescador 1; 31) Río Caleta 4; 32) Puesto Consuelo.

for water travel. Only the Aónikenk were recorded using makeshift rafts (made with tent sticks, branches and/or skins) to cross the Santa Cruz and Chico rivers (Fitzroy 1837: 119; Moreno 1969 [1879]: 242; Burucúa 1974: 54; Lista 1975: 42). Selk' nam escaping from the Salesian Mission on Dawson Island had to be helped by maritime hunter-gatherers to reach the main island of Tierra del Fuego by canoe (Chapman 2007).

(C) Antiquity Publications Ltd. 


\section{Early environment and arrival of humans}

Palaeoecological evidence suggests that the late glacial environment was predominantly open steppe and that the climate was significantly colder and drier than present. After $c$. $10000 \mathrm{BP}$, southern beech woodland expanded into the region from the eastern flanks of the Darwin Cordillera (Markgraf 1993; McCulloch \& Davies 2001) concomitant with a severe arid phase (c. 10 300-8200 BP) during which high charcoal presence suggests an increased frequency of fires. The region-wide nature of the arid phase suggests a climatic cause but the links between early people moving into the region and a higher fire frequency cannot be excluded. A more humid regime is recorded in pollen evidence after $c .8200 \mathrm{BP}$, as the Westerlies returned to their present position (McCulloch \& Morello 2009). The pollen records from Dawson Island (McCulloch \& Davies 2001) suggest that open southern beech woodland reached northern Tierra del Fuego by $c .9000$ BP and expanded eastwards as far as Onamonte by c. $5130 \mathrm{BP}$ (Heusser 1993).

The earliest human occupation of Tierra del Fuego is recorded at the Tres Arroyos 1 rockshelter (Figure 1, no.1), with hearth features dating to c. $10500 \mathrm{BP}$ (Massone et al. 1999a; Massone \& Prieto 2004; Massone 2009). Human occupation was dated at $9590 \pm$ $200 \mathrm{BP}$ at the Marazzi 1 site (Figure 1, no. 2) (Laming-Emperaire et al. 1972), but can be questioned on the basis of a buried soil horizon dated to $8840 \pm 50 \mathrm{BP}$ and bone dated to 4550土40 BP from the same stratigraphic units (Arroyo-Kalin 2009; Morello et al. 2009b). Thus, the earliest bona fide evidence for human occupation after Tres Arroyos 1 comes from the basal components of the Imiwaia 1 and Túnel 1 sites (Figure 1, nos. $3 \& 4$ ), which overlook the northern coast of the Beagle Channel. The assemblages at these sites, dated to $7840 \pm 50 \mathrm{BP}$ and $6680 \pm 210 \mathrm{BP}$, are described as characteristic of terrestrial huntergatherers (Orquera \& Piana 1999, 2009). However, lithic material is rare and some artefact types (rhomboidal lithic points, unifacial tranchets with a polished face and bevels) find no parallels in Fuego-Patagonia at any time range. Poorly preserved faunal remains suggest the consumption of guanaco and sea lion. It is difficult to infer direct relations between these and the Early Holocene occupation of Tres Arroyos 1. Instead, it is suggestive that these sites are located in an area where some of the earliest maritime hunter-gatherer evidence, south of the Strait of Magellan and dated to around 6400 BP, is recorded (Legoupil \& Fontugne 1997; Orquera \& Piana 1999).

\section{Mid Holocene development}

The next signal of terrestrial hunter-gatherers in Tierra del Fuego is provided by occupations dated between 5500 and 3000 BP (Table 1), both on its north-western (Laming-Emperaire et al. 1972; Morello et al. 1999, 2009b) and Atlantic coasts: Laguna Arcillosa (Figure 1, no. 7; Salemme \& Bujalesky 2000; Salemme et al. 2007) and Cerro Las Bandurrias (Figure 1, no. 9; Favier Dubois \& Borrero 2005). Sites typically record the superposition of numerous discrete occupations in thin shell middens (mainly Mytilus edulis) with mixed terrestrial and maritime fauna. A range of lithic artefacts, mainly manufactured with local rocks, include mainly non-diagnostic artefacts such as side- and endscrapers, chopping tools, cores and flakes. Human burials associated with shell midden lenses are found in both

(C) Antiquity Publications Ltd. 


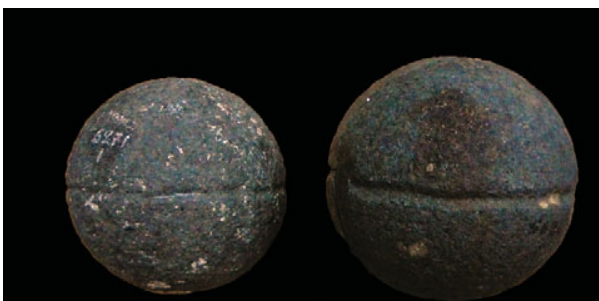

a

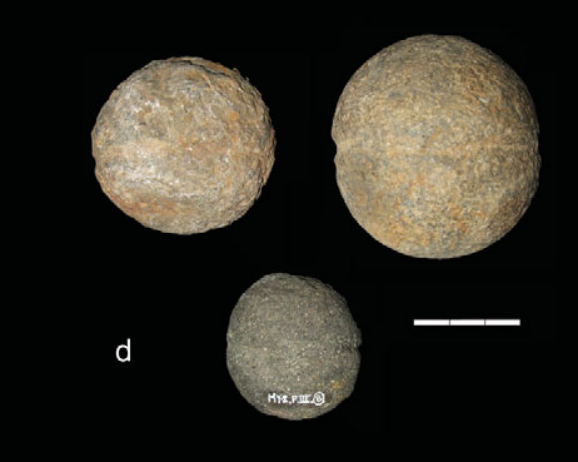

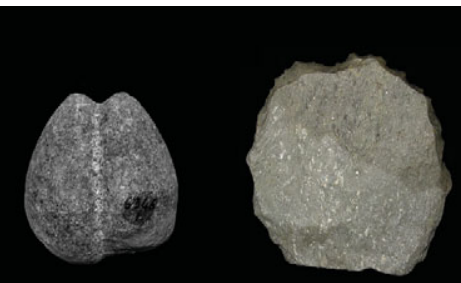

b
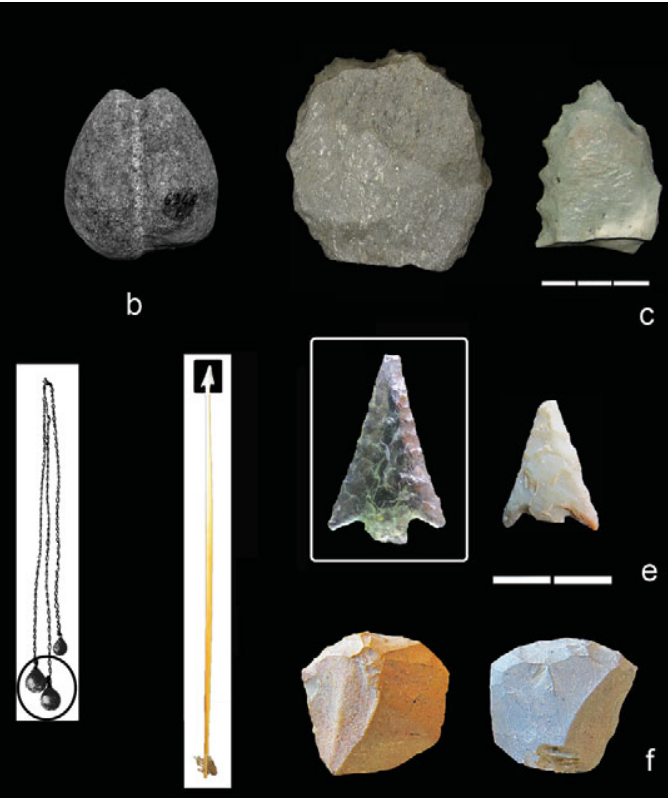

C
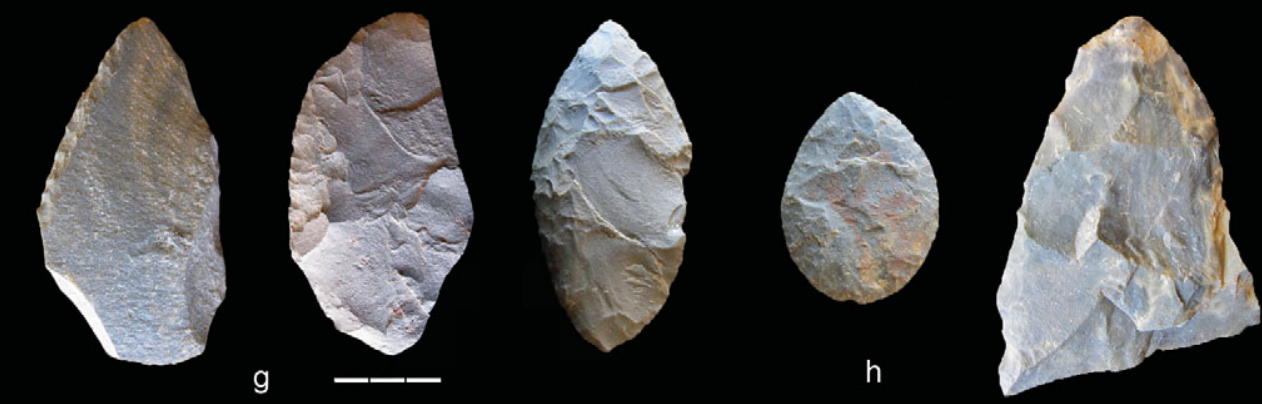

Figure 2. Lithic artefacts: a) spheroid bolas from Marazzi 1, Middle Holocene levels; b) ovoid bola from the same site level; c) denticulate scrapers from Myrén 2; d) spheroid bolas also from Myrén 2; e) ethnographic arrow, glass projectile point, Ona type and Tres Arroyos 1 Ona type projectile point (silex rock); f) two small endscrapers from Tres Arroyos 1, Late Holocene levels; g) sidescrapers from Marazzi 1, Middle Holocene levels; h) bifacial artefacts from Marazzi 1, Middle Holocene levels.

Laguna Arcillosa 2 and Marazzi 1, the latter showing partial cremation (Laming-Emperaire et al. 1972; Guichón 1992; Salemme et al. 2007). Faunal assemblages point to generalised diets based on guanaco consumption, supplemented, perhaps on a seasonal basis, by a diverse array of predictable marine resources. Further inland, the site of Myrén 2 (Figure 1 , no. 10), located some $20 \mathrm{~km}$ north of Inútil Bay, provides evidence of lithic and guanaco remains preserved in waterlogged peat associated with a small freshwater spring. Lithic materials include a small assemblage with uncommon denticulate scrapers and other objects such as the grooved spherical bolas (Figure 2), endscrapers and cores. Three radiocarbon dates suggest occupation events took place around 3900 BP (Massone et al. 1999b; Prieto et al. 2007). Marazzi 13 (Figure 1, no. 11), a rockshelter formed by a large erratic boulder

(C) Antiquity Publications Ltd. 


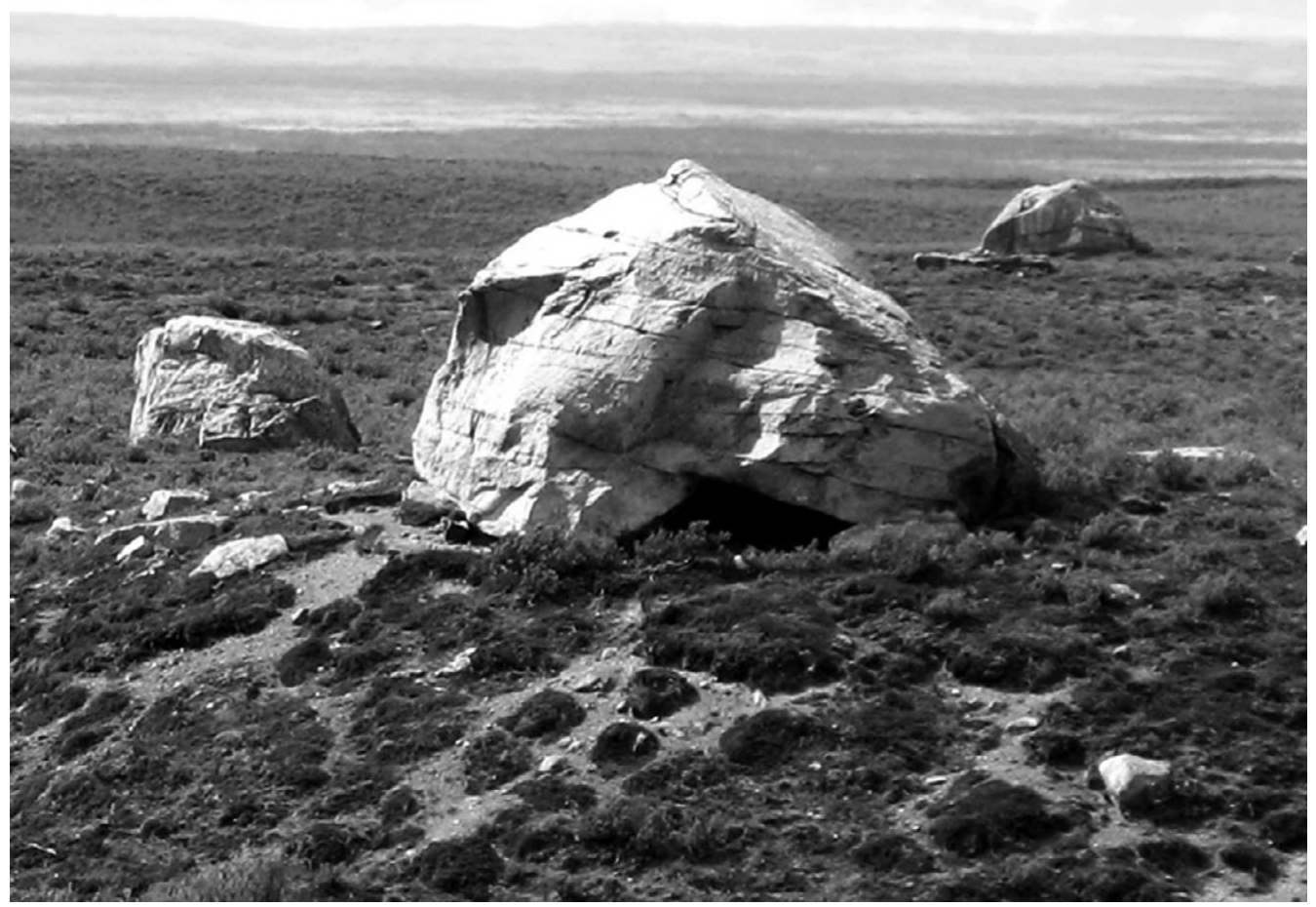

Figure 3. Marazzi 13 site at Bloque de la Obsidiana: general view.

some $8 \mathrm{~km}$ from the coast, shows a hearth with a small lithic assemblage that includes some obsidian (Figures $3 \& 4$, and see below) (Morello et al. 2009b).

\section{The last two millennia}

The large number of archaeological sites dating to the last two millennia suggests significant demographic growth during this period. Redundancy and reoccupation in the use of sites is common, and all the available environments of the island appear to be occupied. This record suggests that effective occupation of space (sensu Borrero 1989-90) had been achieved. Archaeological projectile point types from this period can be linked to arrowheads recorded ethnographically_-in stone and, during the twentieth century, in glass-among Selk'nam terrestrial hunter-gatherers (Figure 2).

In the interior steppe zone, various rockshelters and an open-air occupation in Cerro de los Onas (Figure 1, no. 1), where the Tres Arroyos 1 early site is located, date between 1500 and $700 \mathrm{BP}$. Remains include glass endscrapers, beads and debris, as well as metal remains (C) Antiquity Publications Ltd. 


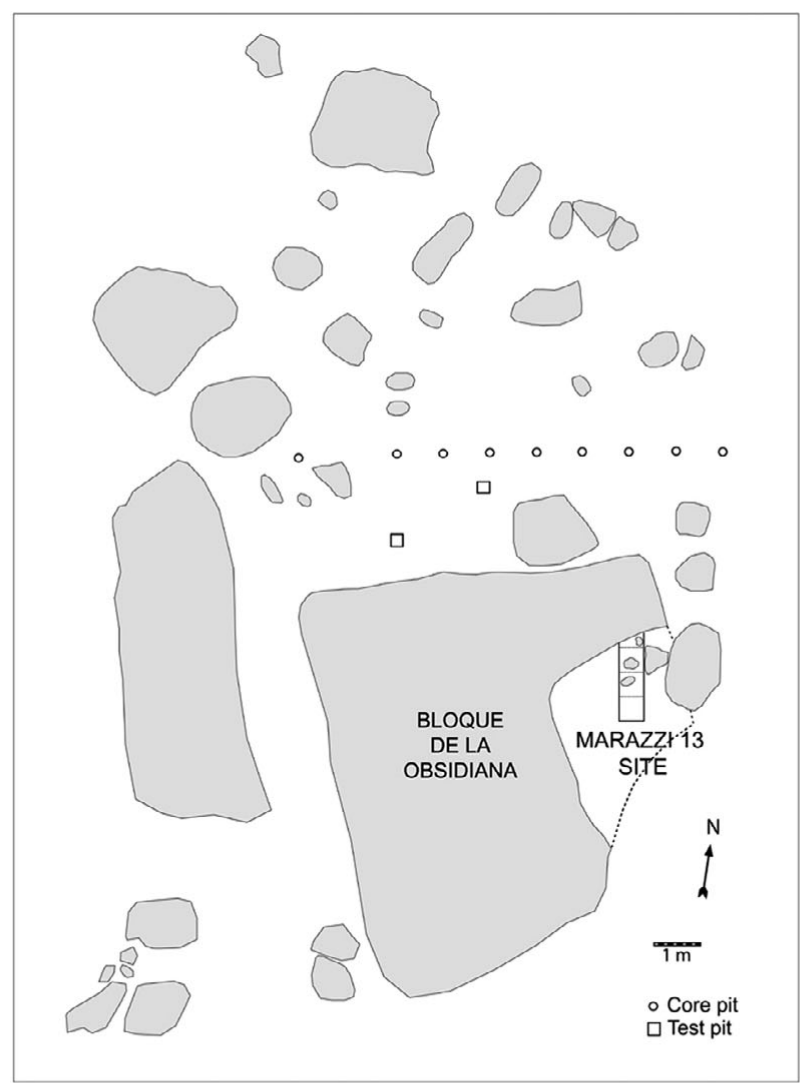

EAST PROFILE

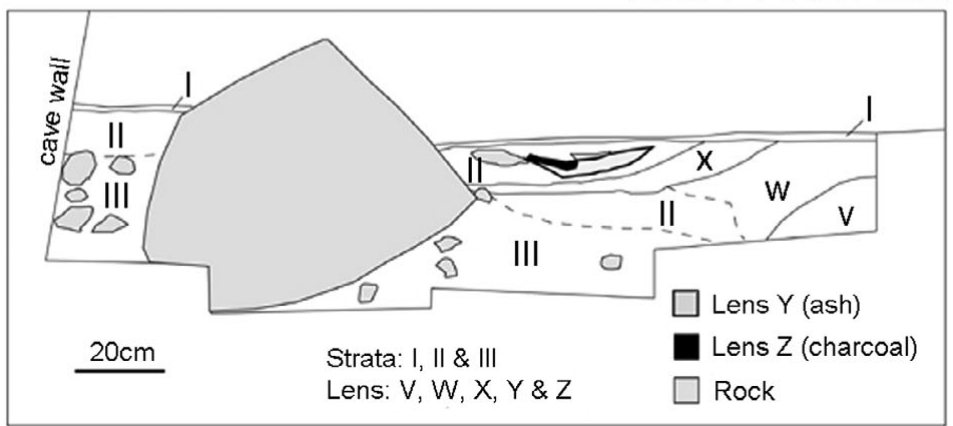

Figure 4. Marazzi 13, plan and profile.

and sheep bone (Massone et al. 1993). Other sites of similar age are found neighbouring saltwater lakes, such as Vergara (Figure 1, no. 15) and Larga (Figure 1, no. 16), and along San Sebastian Bay. In general, faunal assemblages at these sites are dominated by guanaco bones and the lithic toolkit is typical of terrestrial hunter-gatherers.

(C) Antiquity Publications Ltd. 
Table 1. Radiocarbon age information for Tierra del Fuego archaeological sites.

\begin{tabular}{|c|c|c|c|}
\hline Site & ${ }^{14} \mathrm{C}$ years BP & Dated material & Reference \\
\hline \multicolumn{4}{|l|}{$\begin{array}{l}\text { Pleistocene-Holocene } \\
\text { transition }\end{array}$} \\
\hline Tres Arroyos 1 & $\begin{array}{l}10855 \pm 70 \\
10130 \pm 210\end{array}$ & charcoal & $\begin{array}{l}\text { Massone \& Prieto 2004; } \\
\text { Massone } 2009\end{array}$ \\
\hline \multicolumn{4}{|l|}{ Early Holocene } \\
\hline Marazzi 1 & $\begin{array}{l}9590 \pm 200 \\
8840 \pm 50 \\
4550 \pm 40\end{array}$ & $\begin{array}{l}\text { charcoal } \\
\text { sediment (palaeosoil) } \\
\text { bone (indet.) }\end{array}$ & $\begin{array}{l}\text { Laming-Emperaire et al. } \\
\text { 1972; } \\
\text { Morello et al. } 2009 \mathrm{~b} \\
\text { This paper }\end{array}$ \\
\hline Imiwaia 1 & $7840 \pm 50$ & charcoal & Orquera \& Piana 2009 \\
\hline Túnel 1 & $\begin{array}{l}6980 \pm 110 \\
6680 \pm 210\end{array}$ & $\begin{array}{l}\text { charcoal } \\
\text { charcoal }\end{array}$ & $\begin{array}{l}\text { Piana 1984; Piana \& } \\
\quad \text { Orquera } 2009\end{array}$ \\
\hline \multicolumn{4}{|l|}{ Middle Holocene } \\
\hline \multicolumn{4}{|l|}{ Coast } \\
\hline \multirow[t]{2}{*}{ Marazzi 1} & $\begin{array}{l}6170 \pm 50 \\
5570 \pm 400\end{array}$ & $\begin{array}{l}\text { shell (Mytilus sp.) } \\
\text { charcoal }\end{array}$ & $\begin{array}{l}\text { This paper } \\
\text { Laming-Emperaire et al. } \\
1972\end{array}$ \\
\hline & $5440 \pm 30$ & bone (Lama guanicoe) & Morello et al. 1999 \\
\hline Cabo Monmouth 20 & $5520 \pm 50$ & shell (Mytilus sp.) & Morello et al. 2009a \\
\hline Laguna Arcillosa 1 & $5410 \pm 70$ & shell (Mytilus sp.) & $\begin{array}{l}\text { Salemme \& Bujalesky 2000; } \\
\quad \text { Salemme et al. } 2007\end{array}$ \\
\hline Laguna Arcillosa 2 & $\begin{array}{l}5508 \pm 48 \\
5205 \pm 58 \\
4440 \pm 60 \\
3690 \pm 70\end{array}$ & $\begin{array}{l}\text { shell (Mytilus sp.) } \\
\text { bone (Homo sapiens) } \\
\text { shell (Mytilus sp.) } \\
\text { shell (Mytilus sp.) }\end{array}$ & $\begin{array}{l}\text { Salemme \& Bujalesky } \\
\text { 2000; Salemme et al. } 2007\end{array}$ \\
\hline Laguna Arcillosa 3 & $5353 \pm 53$ & shell (Mytilus sp.) & $\begin{array}{l}\text { Salemme \& Bujalesky 2000; } \\
\quad \text { Salemme et al. } 2007\end{array}$ \\
\hline Río Chico 1 & $5856 \pm 44$ & shell (Mytilus sp.) & $\begin{array}{l}\text { Salemme \& Bujalesky 2000; } \\
\quad \text { Salemme et al. } 2007\end{array}$ \\
\hline Cerro Las Bandurrias & $5700 \pm 180$ & shell (Mytilus sp.) & $\begin{array}{l}\text { Favier Dubois \& Borrero } \\
\quad 2005\end{array}$ \\
\hline $\begin{array}{l}\text { Porvenir Norte 12E } \\
\text { Interior }\end{array}$ & \multicolumn{2}{|c|}{ Interior } & Morello et al. 2009b \\
\hline \multirow[t]{2}{*}{ Myrén 2} & $4020 \pm 35$ & bone (Lama guanicoe) & $\begin{array}{l}\text { Massone et al. 1999b; Prieto } \\
\text { et al. } 2007\end{array}$ \\
\hline & $\begin{array}{l}3910 \pm 70 \\
3820 \pm 35\end{array}$ & $\begin{array}{l}\text { bone (Lama guanicoe) } \\
\text { bone (Lama guanicoe) }\end{array}$ & \\
\hline \multicolumn{4}{|l|}{ Late Holocene } \\
\hline \multicolumn{4}{|l|}{ Coast } \\
\hline Punta Baxa 7 & $\begin{array}{l}1820 \pm 40 \\
1360 \pm 40 \\
1210 \pm 40\end{array}$ & $\begin{array}{l}\text { charcoal (feature) } \\
\text { bone (Lama guanicoe) } \\
\text { bone (Lama guanicoe) }\end{array}$ & Morello et al. 2005 \\
\hline Punta Catalina 3 & $\begin{array}{l}2340 \pm 40 \\
2380 \pm 40\end{array}$ & $\begin{array}{l}\text { charcoal (hearth) } \\
\text { charcoal (hearth) }\end{array}$ & Massone \& Torres 2004 \\
\hline
\end{tabular}

(C) Antiquity Publications Ltd. 
Table 1. Continued

\begin{tabular}{|c|c|c|c|}
\hline Site & ${ }^{14} \mathrm{C}$ years $\mathrm{BP}$ & Dated material & Reference \\
\hline Punta Catalina 4 & $1470 \pm 40$ & indet. & Massone \& Morello 2007 \\
\hline Espíritu Santo 1 & $960 \pm 80$ & bone (Lama guanicoe). & Horwitz 2004 \\
\hline Cabo San Vicente I & $\begin{array}{r}2135 \pm 30 \\
805 \pm 40\end{array}$ & $\begin{array}{l}\text { bone (Lama guanicoe) } \\
\text { charcoal }\end{array}$ & $\begin{array}{l}\text { Morello et al. 2009b } \\
\text { Massone \& Morello } 2007\end{array}$ \\
\hline Porvenir Norte 17 & $2850 \pm 60$ & shell (Mytilus sp.) & Morello et al. 2009b \\
\hline Porvenir Norte 19 & $710 \pm 30$ & bone (Lama guanicoe) & Morello et al. 2009b \\
\hline Cabo Monmouth 20 & $2410 \pm 35$ & bone (Lama guanicoe) & Morello et al. 2009a \\
\hline Cabo Monmouth 5 & $1460 \pm 40$ & shell (Mytilus sp.) & Morello et al. 2009b \\
\hline Bahía Inútil 27 & $1600 \pm 50$ & shell (Mytilus sp.) & Morello et al. 2009b \\
\hline \multirow[t]{3}{*}{ Marazzi 2} & $2745 \pm 40$ & charcoal & $\begin{array}{l}\text { Morello et al. 1998; Massone } \\
\quad \text { \& Morello } 2007\end{array}$ \\
\hline & $1965 \pm 40$ & bone (Lama guanicoe) & \\
\hline & $910 \pm 70$ & bone (Lama guanicoe) & \\
\hline \multirow{2}{*}{ Marazzi 32} & $635 \pm 35$ & charcoal (feature) & Massone \& Morello 2007 \\
\hline & $560 \pm 35$ & charcoal (feature) & \\
\hline \multirow[t]{2}{*}{ Marazzi 38} & $795 \pm 35$ & charcoal (feature) & Massone \& Morello 2007 \\
\hline & $785 \pm 35$ & charcoal (feature) & \\
\hline La Ballena 2 & $740 \pm 35$ & bone (Lama guanicoe) & Morello et al. 2009b \\
\hline Taca Taca Sur & $2970 \pm 130$ & bone (Lama guanicoe) & Morello et al. 2009b \\
\hline $\begin{array}{l}\text { Bloque El Maucho } \\
\text { (BIS41) }\end{array}$ & $935 \pm 35$ & bone (Lama guanicoe) & Morello et al. 2009b \\
\hline $\begin{array}{l}\text { Bloque El Hediondo } \\
\text { (BIS46) }\end{array}$ & $1470 \pm 35$ & bone (Lama guanicoe) & Morello et al. 2009b \\
\hline Cabeza de León 1-4 & $1100 \pm 95$ & charcoal (hearth) & $\begin{array}{l}\text { Borrero 1979; Martin \& } \\
\quad \text { Borella } 1999\end{array}$ \\
\hline Bloque Errático 1 & $785 \pm 120$ & bone (Lama guanicoe) & Borrero \& Casiraghi 1980 \\
\hline Puesto Pescador 1 & $335 \pm 35$ & $\begin{array}{l}\text { bone (Homo sapiens } \\
\text { sapiens) }\end{array}$ & Suby et al. 2008 \\
\hline \multirow[t]{5}{*}{ San Genaro 1} & $610 \pm 45$ & bone (Lama guanicoe) & Horowitz 1995, 2004 \\
\hline & $1070 \pm 80$ & charcoal & \\
\hline & $1190 \pm 90$ & shell (Mytilus sp.) & \\
\hline & $1479 \pm 95$ & shell (Mytilus sp.) & \\
\hline & $1620 \pm 140$ & shell (Patinigera sp.) & \\
\hline \multirow[t]{3}{*}{ San Genaro 2} & $380 \pm 70$ & bone (Lama guanicoe) & Horwitz 1995, 2004 \\
\hline & $440 \pm 70$ & bone (Lama guanicoe) & \\
\hline & $1483 \pm 80$ & shell (Mytilus sp.) & \\
\hline San Genaro 3 & $600 \pm 90$ & shell (Mytilus sp.) & Favier Dubois 2001 \\
\hline San Genaro 4 & modern & $\begin{array}{l}\text { bone (Homo sapiens } \\
\text { sapiens) }\end{array}$ & Martin et al. 2004 \\
\hline Cerro 'Sin Nombre' & $1250 \pm 60$ & bone (Lama guanicoe) & $\begin{array}{l}\text { Favier Dubois \& Borrero } \\
\quad 2005\end{array}$ \\
\hline Cerro de los Gatos & $900 \pm 115$ & gastropods & $\begin{array}{l}\text { Favier Dubois \& } \\
2005\end{array}$ \\
\hline \multirow[t]{2}{*}{ Punta Maria 2} & $300 \pm 100$ & charcoal (hearth) & Borrero 1986 \\
\hline & $720 \pm 50$ & bone (Lama guanicoe) & \\
\hline
\end{tabular}

(C) Antiquity Publications Ltd. 
Table 1. Continued

\begin{tabular}{lcll}
\hline Site & ${ }^{14}$ C years BP & Dated material & \\
& $1230 \pm 50$ & bone (Lama guanicoe) & \\
& $2300 \pm 90$ & bone (whale) & \\
& $2720 \pm 340$ & charcoal (hearth) & \\
Interior & & & \\
Tres Arroyos 1 & $1340 \pm 50$ & charcoal (feature) & Massone et al. 1993 \\
& $700 \pm 70$ & charcoal (feature) & \\
Tres Arroyos 14(89) & $280 \pm 70$ & charcoal (feature) & Massone et al. 1993 \\
& $210 \pm 50$ & charcoal (feature) & \\
Tres Arroyos 14(30) & $2280 \pm 60$ & bone (Lama guanicoe) & Prieto et al. 1997 \\
Tres Arroyos 7 & $100 \pm 50$ & indet. & Massone et al. 1993 \\
Laguna Larga F1 & $1410 \pm 100$ & bone (Lama guanicoe) & This paper \\
Laguna Larga F4 & $285 \pm 35$ & bone (Lama guanicoe) & This paper \\
Lago Vergara E23 & $2560 \pm 140$ & bone (Lama guanicoe) & This paper \\
Lago Vergara E24 & $360 \pm 30$ & bone (Lama guanicoe) & This paper \\
Lago Vergara J24 & $855 \pm 35$ & bone (Lama guanicoe) & This paper \\
La12 & $310 \pm 60$ & bone (Lama guanicoe) & Massone et al. 1993 \\
Riachuelo Puesto Nuevo & $1210 \pm 30$ & bone (Lama guanicoe) & This paper \\
J17 & & & \\
Avilés 1 & $1609 \pm 38$ & bone (Lama guanicoe) & Santiago \& Oría 2007 \\
Las Vueltas 1 & $949 \pm 41$ & bone (Lama guanicoe) & Santiago \& Salemme 2009 \\
Forest & $950 \pm 50$ & bone & \\
Fagnano 1, Locus 2 & $1800 \pm 250$ & charcoal (hearth) & Mamos \& Merenzon 2002-2004 \\
Marina 1 & $900 \pm 170$ & charcoal (hearth) & \\
Lago Blanco 1 & $3180 \pm 40$ & charcoal (hearth) & This paper \\
\hline
\end{tabular}

The coastal zone is rich in archaeological remains but only a few occupations have been precisely dated. At Primera Angostura, lithic, bone remains and shell layers are distributed almost continuously over several kilometres. Within this complex, occupation has been dated to between 1800 and 1200 BP at Punta Baxa 7 (Figure 1, no. 13) (Morello 2000; Morello et al. 2005) and to $c .2300 \mathrm{BP}$ at Punta Catalina 3 (Figure 1, no. 14). The latter is a shell midden with abundant land and marine faunal remains, along with large quantities of fish bones and fishing net weights made of stone (Massone \& Torres 2004). Further to the south, other sites are recorded in the vicinity of Inútil Bay. These include Marazzi 2 (Figure 1, no. 21) (2745-970 BP), Marazzi 32 and 38 (Figure 1, no. 2), with dates $c .700$ and 600 BP (Morello et al. 1998, 2004; Massone \& Morello 2007), sites in erratic boulders (rockshelters in Bloque El Maucho-BIS41 and Bloque El Hediondo-BIS46, Figure 1, no. 22) and open-air sites (La Ballena 2 and Taca Taca Sur, Figure 1, no. 22; see Table 1).

On the Atlantic coast, a number of small tertiary outcrops and erratic boulders record Late Holocene occupations: Cerro 'Sin Nombre', Cerro de los Gatos, Cabeza de León, Bloque Errático 1 (Figure 1, nos. 9 \& 18; Table 1). At San Genaro, near San Sebastián (C) Antiquity Publications Ltd. 
Bay (Figure 1, no. 19), dates start around $1600 \mathrm{BP}$ and reach early modern times (Borrazzo 2004). Further to the south, Punta María 2 (Figure 1, no. 24) records a sequence of repeated occupations focused on the acquisition of marine resources from $c$. 3000-300 BP (Borrero 1986).

It is important to point out that the high density of sites in some parts of Tierra del Fuego could partly reflect the intensity of archaeological research since the early 1960 s (e.g. Laming-Emperaire 1972a \& b; Laming-Emperaire et al. 1972; Massone 1997, 2004; Massone et al. 2003; Borrero \& Barberena 2004). The intensity of research in the centralsouthern part of the island, which is dominated by mountains and forests, is much lower and thus site densities are not comparable. However, a date of $3180 \mathrm{BP}$ at Lago Blanco 1 (Figure 1, no. 27) (this paper) provides evidence for occupation in the 5000-3000 BP time range. Occupations at Marina 1 (Figure 1, no. 26) (Mansur et al. 2000) are dated between 1800 and 900 BP. Strong ethnographic evidence exists of Selk'nam occupations in Lago Fagnano (Chapman 2007).

\section{Interaction}

Discussion about interaction, contact and mobility in pre-Columbian Fuego-Patagonia has focused on diagnostic artefacts, especially projectile points and bolas (Figure 2) (LamingEmperaire 1972a \& b; Bird 1993). More recently, decorated bone instruments and the mobile art of canoe groups have also been discussed (Fiore 2006). However, it is difficult to employ this type of evidence to discuss interaction patterns of terrestrial groups because all Fuego-Patagonia assemblages share a common cultural baggage that is punctuated by roughly synchronic changes over time. Clear diagnostic types emerge only during the Late Holocene, mainly the small, stemmed projectile points (arrowheads) known as the Ona type.

More useful indicators of interaction are finds of obsidian artefacts at terrestrial huntergatherer sites (see Figure 1). At Marazzi 13, also known as 'Bloque de la Obsidiana' (Figure 1, no. 11), a small number of flakes $(n=12)$ are of black and green obsidian. The lithic remains are associated with an ashy lens (small hearth feature, Figure 4) dated to c. $3930 \mathrm{BP}$ (Morello et al. 2009b). Apart from a 45mm-long green obsidian flake, all lithic pieces are small $(<30 \mathrm{~mm})$. Seven black obsidian pieces are mainly internal flakes or fragments, one split debris, and another is a flake fragment with some remaining cortex. The assemblage suggests a curation strategy.

Recent studies show that Patagonian black obsidian comes from a unique source some $600 \mathrm{~km}$ north of the Strait of Magellan, at the Pampa del Asador (PDA) (Figure 5). Its presence, widespread throughout Patagonia, is restricted to Holocene age terrestrial huntergatherers. In the quarry three chemical types have been identified, with four to six sub-types (Stern 2000, 2004). Two archaeological samples of black obsidian from the Marazzi 13 site were analysed using bulk laser ablation ICP-MS analysis and results correspond to two different chemical sub-types from Pampa del Asador: PDA1 and PDA2 (Table 2; Figure 6). Green obsidian also has a unique source, located in an unknown location near the Otway Sea and Riesco Island. 


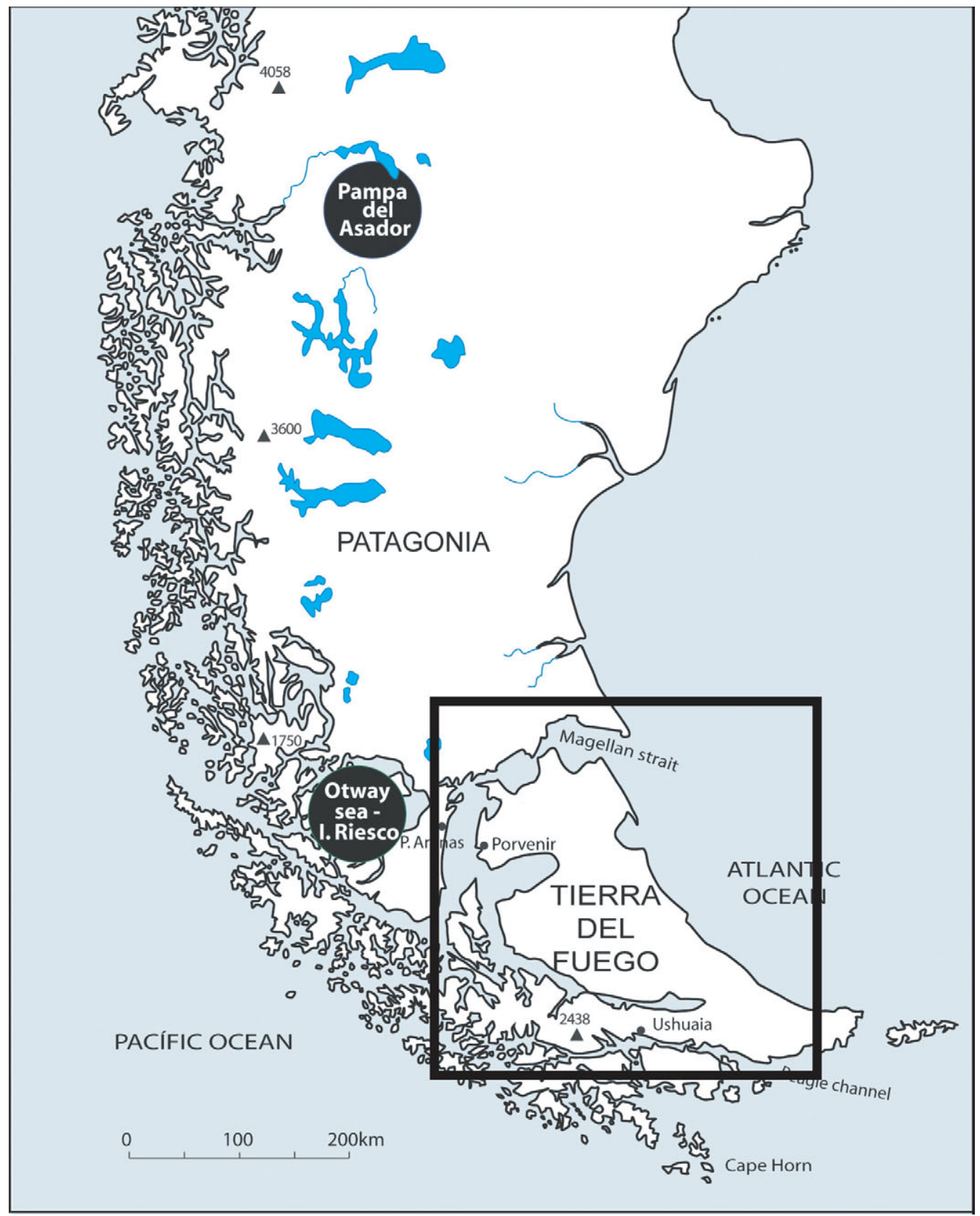

Figure 5. Obsidian sources in Patagonia.

Other variability is suggestive: while in mainland Patagonia boleadoras remained in use until the twentieth century and bolas are found in archaeological assemblages from early on, in Tierra del Fuego bolas disappear from terrestrial hunter-gatherer sites around 1500 BP, (C) Antiquity Publications Ltd. 


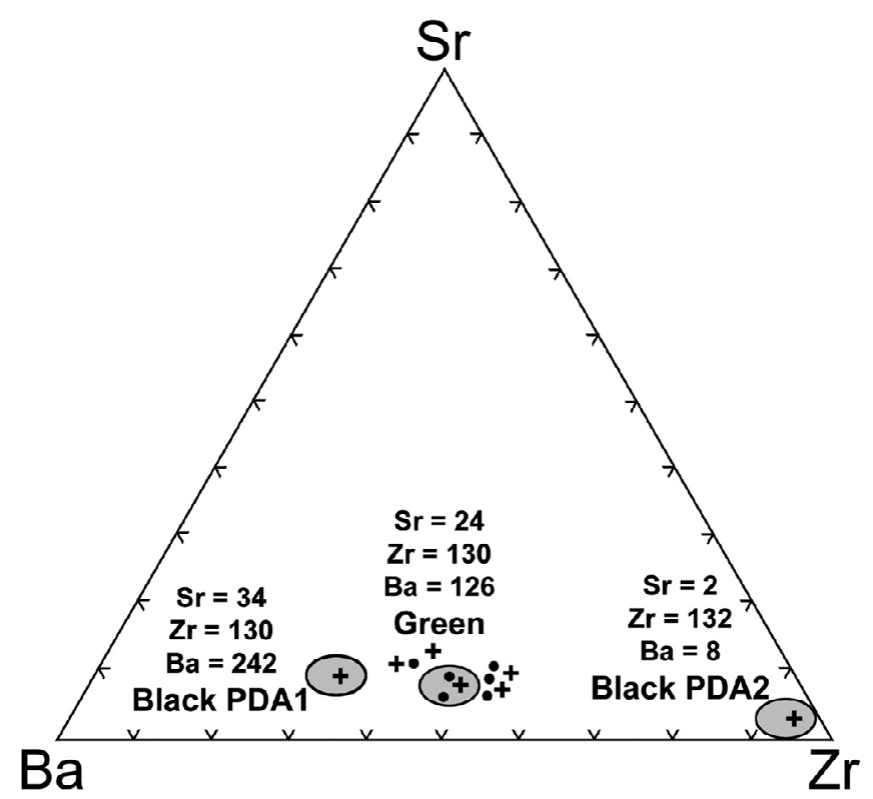

Figure 6. Chemical composition ranges of green and black obsidian (shaded fields) determined by bulk XRF and ICP-MS analysis of larger samples. Smaller samples analysed by laser ablation ICP-MS techniques are indicated by plus signs $(+)$ for obsidian artefacts from Tierra del Fuego, and solid dots for artefacts from other locations (Table 2).

implying abandonment of the technology. Ethnographic records do not mention their use among the Selk'nam (Torres 2009).

\section{Discussion and conclusion}

As a result of recent investigations we now understand something of the development of human occupation in Tierra del Fuego from $c .10500$ years ago to the indigenous Selk'nam society observed over the last few hundred years. A gap exists between early (c. 10500 BP) and Middle Holocene (c. 5000 BP) occupations, and a series of hypotheses have been advanced to explain it, including local extinction or out-migration of early late-glacial groups (Borrero 1996; Borrero \& McEwan 1997). In theory, harsh environmental conditions and natural barriers forming at $c .8000 \mathrm{BP}$ could have caused independent and discontinuous development. However, the arrival at $c .6500 \mathrm{BP}$ of maritime groups distinct from FuegoPatagonian terrestrial hunter-gatherers (Legoupil \& Fontugne 1997; Alvarez 2004; Fiore 2006; Piana \& Orquera 2009) may have partially transformed biogeographic barriers into a 'water bridge' (Fiore 2006). Over two time periods - an initial strong pulse between $c$. 5000 and $3000 \mathrm{BP}$ and another within the last 1000 years-the central portion of the Strait of Magellan may have become a crucial route for intergroup exchange, minimally leading to circulation of raw material (obsidian) and an intangible flow of ideas and artefact morphology. Thus, archaeological evidence makes it increasingly clear that canoe peoples

(C) Antiquity Publications Ltd. 
Table 2. Trace-element compositions of obsidian samples from Tierra del Fuego (TDF) and rock sources.

\begin{tabular}{llccc}
\hline & \multicolumn{1}{c}{ Site } & Sr & Zr & Ba \\
\hline Green obsidian from TDF & & & & \\
AGOB-5 & Marazzi 13 & 20 & 80 & 101 \\
AGOB-8 & Marazzi 1 & 8 & 53 & 36 \\
AGOB-6 & Marazzi 22 & 19 & 79 & 75 \\
AGOB-9 & Porvenir Norte 28 & 11 & 71 & 51 \\
CS4 & Río Caleta 4 & 11 & 79 & 71 \\
Green obsidian from elsewhere & & & & \\
AGOB-7 & Cabo León & 11 & 66 & 48 \\
AGOB-4 & Río Batchelor & 16 & 65 & 78 \\
AGOB-3 & Río Batchelor & 11 & 67 & 45 \\
AGOB-1 & Tilland 1 & 10 & 59 & 51 \\
Green1 & Seno Otway & 14 & 81 & 74 \\
Green2 & Seno Otway & 12 & 90 & 72 \\
Black obsidian from TDF & & & & \\
CS7 (identified as type PDA1) & Marazzi 13 & 29 & 108 & 192 \\
MM1 (identified as type PDA2) & Marazzi 13 & 2 & 127 & 6 \\
Black obsidian from elsewhere & & & & \\
CS-PDA1 & Pampa del Asador & 26 & 104 & 220 \\
CS-PDA2 & Pampa del Asador & 1 & 103 & 6 \\
CS951 (green) & Puesto Consuelo 3 & 24 & 155 & 105 \\
Green bulk & Seno Otway & 24 & 130 & 126 \\
PDA1 bulk & Pampa del Asador & 34 & 130 & 242 \\
PDA2 bulk & Pampa del Asador & 2 & 132 & 8 \\
\hline
\end{tabular}

Lasar-ablation Sr, Ba and $\mathrm{Zr}$ data and bulk ICP-MS analysis in parts per million (ppm).

helped to mitigate the effects of insularisation on Tierra del Fuego's terrestrial huntergatherers during the second half of the Holocene.

\section{Acknowledgements}

Research funded by grant FONDECYT 1060020 and FONDECYT, Incentivo a la Cooperación Internacional 7070071 and 7060304 . We thank José Luis Lanata for funding the TOF-ICP-MS obsidian analysis, Karen Borrazzo and Donald Jackson.

\section{References}

AlvareZ, M. 2004. Estrategias tecnológicas en los grupos canoeros tempranos del área Fuego-Patagónica. Magallania 32: 191-208.

Arroyo-KaLin, M. 2009. Reevaluando la estratigrafía del sitio Marazzi 1: una primera aproximación desde la micromorfología de suelos. Proyecto FONDECYT 1060020. Unpublished manuscript, Chile.

BIRD, J. 1993. Viajes y arqueología en Chile austral. Punta Arenas: Universidad de Magallanes.
Borrazzo, K. 2004. Capítulo 3. Tecnología lítica y uso del espacio en la Costa Norte Fueguina, in L. Borrero \& R. Barberena (ed.) Temas de Arqueología. Arqueología del norte de la Isla Grande de Tierra del Fuego: 55-86. Buenos Aires: Editorial Dunken.

Borrero, L. 1979. Excavación en el alero 'Cabeza de León’, Tierra del Fuego. Relaciones (new series) 13: 255-71.

- 1986. La economía prehistórica de los habitantes del norte de la Isla Grande de Tierra del Fuego. Unpublished PhD dissertation, Universidad de Buenos Aires.

(C) Antiquity Publications Ltd. 
-1989-90. Evolución cultural divergente en la Patagonia austral. Anales del Instituto de la Patagonia, Serie Ciencias Humanas 19: 133-40.

- 1996 The Pleistocene-Holocene transition in southern South America, in L.G. Straus, B. Eriksen, J. Erlandson \& D. Yesner (ed.) Humans at the end of the Ice Age: the archaeology of the PleistoceneHolocene transition: 339-54. New York: Plenum.

Borrero, L. \& R. BArberena (ed.). 2004. Arqueología del norte de la Isla Grande de Tierra del Fuego. Buenos Aires: Editorial Dunken.

Borrero, L. \& M. Casiraghi. 1980. Excavaciones en el Sitio Bloque Errático 1 San Sebastián, Tierra del Fuego. Relaciones (new series) 14: 129-42.

Borrero, L. \& C. MCEWAN. 1997 The peopling of Patagonia: the first human occupation, in C. McEwan, L. Borrero \& A. Prieto (ed.) Patagonia. Natural history, prehistory and ethnography at the uttermost end of the earth: 32-45. London: British Museum Press.

BurucúA, J.E. 1974. Viajes de Antonio de Viedma: los establecimientos de Puerto Deseado y San Julián. Segundo Congreso de Historia Argentina y Regional 1: 41-62.

Chapman A. 2007. Los Selknam: la vida de los onas en Tierra del Fuego. Buenos Aires: Emecé Editores.

Cherry, J.F. 1981. Pattern and process in the earliest colonization of the Mediterranean islands. Proceedings of the Prehistoric Society 47: 41-68.

DERrICOURT, R. 2005. Getting 'out of Africa': sea crossings, land crossings and culture in Hominin migrations. Journal of World Prehistory 19: 119-32.

Favier Dubois, C. 2001. Análisis geoarqueológico de los procesos de formación del registro, cronología y paleoambientes, en sitios arqueológics de Fuego-Patagonia. Unpublished PhD dissertation, Universidad de Buenos Aires.

Favier Dubois, C. \& L. Borrero. 2005. Playas de acreción: cronología y procesos de formación del registro arqueológico en la costa central de la bahía San Sebastián, Tierra del Fuego Argentina. Magallania 332: 93-108.

FIORE, D. 2006. Puentes de agua para el arte mobiliar: la distribución espacio-temporal de artefactos óseos decorados en Patagonia meridional y Tierra del Fuego. Cazadores-Recolectores del Cono Sur, Revista de Arqueología 1: 137-47.

FITZROY, R. 1837. Extracts from the diary of an attempt to ascend the river Santa Cruz, in Patagonia, with the boats of His Majesty's sloop Beagle. Journal of the Royal Geographical Society of London 7: 114-26.

GUICHÓN, R. 1992. Informe preliminar sobre el enterratorio con cremación del sitio marazzi. Anales del Instituto de la Patagonia, Serie Ciencias Humanas 21: 109-112.
Heusser, C. 1993. Late Quaternary forest-steppe contact zone, Isla Grande de Tierra del Fuego, subantarctic South America. Quaternary Science Reviews 123: 169-77.

HorwITZ, V. 1995. Ocupaciones prehistóricas en el sur de bahía San Sebastián Tierra del Fuego, Argentina. Arqueología 5: 105-136.

- 2004. Capítulo 2. Arqueología de la costa atlántica septentrional de Tierra del Fuego, Argentina, in L. Borrero \& R. Barberena (ed.) Arqueología del norte de la Isla Grande de Tierra del Fuego: 30-53. Buenos Aires: Editorial Dunken.

LAMING-EMPERAIRE, A. 1972a. Pêcheurs des archipels et chasseurs des pampas. Objets et Mondes 122: 167-84.

- 1972b. Sites préhistoriques de Patagonie chilienne. Objets et Mondes 122: 201-224.

Laming-Emperaire, A., D. Lavallée \& R. Humbert. 1972. Le site de Marazzi en Terre de Fue. Objets et Mondes 122: 225-44.

Legoupil, D. \& R. Fontugne. 1997. El Poblamiento marítimo en los archipiélagos de Patagonia: núcleos antiguos y dispersión reciente. Anales del Instituto de la Patagonia, Serie Ciencias Humanas 25: 75-87.

LISTA, R. 1975. Mis exploraciones y descubrimientos en la Patagonia (1877-1880). Buenos Aires: Ediciones Marymar.

Mansur, M.E., D. Martinioni \& A. LASA. 2000. La gestión de los recursos líticos en el sitio Marina 1 zona central de Tierra del Fuego, Argentina, in J.B. Belardi, F. Carballo \& S. Espinosa (ed.) Desde el País de los Gigantes. Perspectivas arqueológicas en Patagonia (Tomo I): 57-72. Rio Gallegos: Universidad Nacional de la Patagonia Austral.

MARKGRAF, V. 1993. Paleoenvironments and paleoclimates in Tierra del Fuego and southernmost Patagonia, South America. Palaeogeography, Palaeoclimatology, Palaeoecology 1021/2: 53-68.

Martin, F. \& F. Borella. 1999. Tafonomía de Tierra del Fuego: reevaluación de la arqueología de Cabeza de León, in M.T. Civalero, P. Fernández \& A.G. Guráieb (ed.) Soplando en el Viento. Actas de las III Jornadas de Arqueología de la Patagonia. Neuquén-Buenos Aires: Instituto Nacional de Arqueología y Pensamiento Latinoamericano y Universidad de Comahue.

Martin, F., R. Barberena \& R. Guichón. 2004. Erosión y restos humanos. El caso de la localidad Chorrillos, Tierra del Fuego. Magallania 32: 125-42.

Massone, M. 1997. Prospección arqueológica del sector comprendido entre los ríos Marazzi y Torcido, zona norte de Tierra del Fuego. Anales del Instituto de la Patagonia, Serie Ciencias Humanas 25: 123-36.

- 2004. Los cazadores después del hielo. Santiago: Dirección de Bibliotecas, Archivos y Museos. 
- 2009. Abrigos rocosos de Magallanes en la transición Pleistoceno-Holoceno, in A. Troncoso (ed.) Actas XVII Congreso Nacional de Arqueología Chilena, Valdivia 2006: 729-40. Valdivia: Ediciones Kultrún.

Massone, M. \& F. Morello. 2007. Los Cetáceos en el Mundo Selk'nam: una evaluación arqueológica, in F. Morello, M. Martinic, A. Prieto \& G. Bahamonde (ed.) Arqueología de Fuego-Patagonia. Levantando piedras, desenterrando huesos. . y develando arcanos: 709-721. Punta Arenas: Ediciones CEQUA.

Massone, M. \& A. Prieto. 2004. Evaluación de la Modalidad Cultural Fell 1 en Magallanes. Chungará 36(suppl.): 303-315.

Massone, M. \& J. Torres. 2004. Pesas, peces y restos de cetáceos en el campamento de Punta Catalina 3 2.300 años AP. Magallania 32: 143-61.

Massone, M., D. Jackson \& A. PRieto. 1993. Perspectiva arqueológica de los Selk'nam. Santiago: Editorial Universitaria.

Massone, M., A. Prieto, D. Jackson, G. Cardenas, M. ARroyo \& P. CARdenAS. 1999a. Los cazadores tempranos y sus fogatas: una nueva historia para la Cueva Tres Arroyos 1, Tierra del Fuego. Boletín de la Sociedad Chilena de Arqueología 26: 11-18.

Massone, M., A. Prieto, D. Jackson, X. Prieto, G. Rojas \& R. SEguel. 1999b. Hombre temprano y paleoambiente en Tierra del Fuego. Proyecto FONDECYT 1960027. Unpublished manuscript, Punta Arenas, Chile.

Massone, M., F. Morello, A. Prieto, M. San Román, F. Martin \& P. Cardenas. 2003. Sitios arqueológicos, restos de cetáceos y territorios locales Selk' nam en bahía Inútil, Tierra del Fuego. Magallania 31: 45-60.

McCulloch, R. \& S.J. Davies. 2001. Late-glacial and Holocene palaeoenvironmental change in the central Strait of Magellan, southern Patagonia. Palaeogeography, Palaeoclimatology, Palaeoecology 173: 143-73.

McCulloch, R. \& F. Morello. 2009. Evidencia glacial y paleoecológica de ambientes tardiglaciales y del Holoceno temprano. Implicaciones para el poblamiento temprano de Tierra del Fuego, in M. Salemme, F. Santiago, M. Álvarez, E. Piana, M. Vázquez \& M.E. Mansur (ed.) Arqueología de Patagonia: una mirada desde el último confin: 119-36. Ushuaia: Editorial Utopías.

McCulloch, R., M.J. Bentley, R.M. Tipping \& C. Clapperton. 2005. Evidence for late-glacial ice dammed lakes in the central Strait of Magellan and Bahía Inútil, southernmost South America. Geografiska Annaler 87A(2): 335-62.
Morello, F. 2000. Registro arqueológico de sitios de Primera Angostura, Tierra del Fuego. Proyecto FONDART 51237. Unpublished manuscript, Chile.

Morello, F., M. San Román, R. Seguel \& F. MARTIN. 1998. Excavación en el sitio Marazzi 2. Sector 2 - Terraza superior (Río Torcido, Bahía Inútil). Primer avance. Anales del Instituto de la Patagonia, Serie Ciencias Humanas 26: 119-26.

Morello, F., L. Contreras \& M. San Román. 1999. La localidad de Marazzi y el sitio arqueológico Marazzi 1, una reevaluación. Anales del Instituto de la Patagonia, Serie Ciencias Humanas 27: 183-98.

Morello, F., M. San Román \& A. Prieto. 2004. Obsidiana verde en Fuego-Patagonia: distribución y estrategias tecnológicas, in M.T. Civalero, P. Fernandez \& A.G. Guraieb (ed.) Contra viento y marea. Arqueología de Patagonia: 149-66. Buenos Aires: INAPL-SAA.

Morello, F., L. Contreras, M. San Román, I. Martinez, F. Martin \& M. Bahamondes. 2005. El sitio Punta Baxa 7, Primera Angostura, Tierra del Fuego. Proyecto FONDECYT 1020004. Unpublished manuscript, Chile.

Morello, F., M. Arroyo-Kalin, L. Borrero, J. Torres, M. Massone, P. CÁrdenas \& G. BAHAMONDE. 2009a. Nuevas evidencias de cazadores recolectores terrestres del Holoceno medio y tardío en Tierra del Fuego: el sitio Cabo Monmouth 20. Magallania 37(2): 191-203.

Morello, F., L. Borrero, J. Torres, M. Massone, M. Arroyo-Kalin, R. McCulloch, E. Calas, M. Lucero, I. Martínez \& G. BAhamonde. 2009b. Evaluando el registro arqueológico de Tierra del Fuego durante el Holoceno temprano y medio, in M. Salemme, F. Santiago, M. Alvarez, E. Piana, M. Vázquez \& M.E. Mansur (ed.) Arqueología de Patagonia: una mirada desde el último confin: 1075-1092. Ushuaia: Editorial Utopías.

Moreno, F.P. 1969 [1879]. Viaje a la Patagonia austral, 1876-1877. Buenos Aires: Solar-Hachette.

Orquera, L.A. \& E. Piana. 1999. Arqueología de la región del canal Beagle (Tierra del Fuego, República Argentina). Buenos Aires: Sociedad Argentina de Antropologia.

- 2009. Sea nomads of the Beagle Channel in southernmost South America: over six thousand years of coastal adaptation and stability. Journal of Island \& Coastal Archaeology 4: 61-81.

PIANA, E. 1984. Arrinconamiento o adaptación en Tierra del Fuego, in E. Belgrano (ed.) Ensayos de Antropología Argentina: 9-110. Buenos Aires: Editorial de la Universidad de Belgrano.

PiAnA, E. \& L.A. OrQUERA. 2009. The southern top of the world: the first peopling of Patagonia and Tierra del Fuego, and the cultural endurance of Fuegian sea-nomads. Arctic Anthropology 46(1-2): 103-117.

(C) Antiquity Publications Ltd. 
PISANO, E. 1977. Fitogeografía de Fuego-Patagonia chilena. 1: Comunidades vegetales entre las latitudes $52^{\circ}$ y $56^{\circ} \mathrm{S}$. Anales del Instituto de la Patagonia 8: 121-250.

Prieto, A., F. Martin \& M. Arroyo. 1997. Excavación del sitio TA-14(30) NE. Proyecto FONDECYT 1960027. Unpublished manuscript, Chile.

Prieto, A., E. Calás, F. Morello \& J. Torres. 2007. El sitio arqueológico Myrén 2, Tierra del Fuego, Chile. Magallania 35(2): 89-103.

Ramos, M. \& J. Merenzon. 2002-2004. Misión franco-argentina en el centro de la isla de Tierra del Fuego: análisis general sobre los conjuntos líticos hallados. Arqueología 12: 213-38.

Salemme, M. \& G. Bujalesky. 2000. Condiciones para el asentamiento humano litoral entre Cabo San Sebastián y Cabo Peñas (Tierra del Fuego) durante el Holoceno medio, in J.B. Belardi, F. Carballo \& S. Espinosa (ed.) Desde el País de los Gigantes. Perspectivas arqueológicas en Patagonia. Río Gallegos: Universidad Nacional de la Patagonia Austral.

Salemme, M., G. Bujalesky \& F. SAntiago. 2007. La Arcillosa 2: la ocupación humana durante el Holoceno medio en río Chico, Tierra del Fuego, Chile, in F. Morello, M. Martinic, A. Prieto \& G. Bahamonde (ed.) Arqueología de Fuego-Patagonia. Levantando piedras, desenterrando huesos. . y develando arcanos: 723-36. Punta Arenas: Ediciones CEQUA.
Santiago, F. \& J. Oría. 2007. Lo que el viento no se llevó. Análisis de sitios de superficie en la estepa fueguina. Magallania 352: 121-32.

Santiago, F. \& M. Salemme. 2009. Las Vueltas 1: un sitio de matanza de guanacos del Holoceno tardío en el norte de Tierra del Fuego (Argentina), in M. Salemme, F. Santiago, M. Álvarez, E. Piana, M. Vázquez \& M.E. Mansur (ed.) Arqueología de Patagonia: una mirada desde el último confin: 825-44. Ushuaia: Editorial Utopías.

STERN, C. 2000. Fuentes de los artefactos de obsidiana en los sitios arqueológicos de las cuevas de Pali Aike y Fell, y Cañadón La Leona, en Patagonia Austral. Anales del Instituto de la Patagonia, Serie Ciencias Humanas 28: 251-63.

- 2004. Obsidian in southern Patagonia: review of the current information, in M.T. Civalero, P. Fernández \& A.G. Guráieb (ed.) Contra viento y marea. Arqueología de Patagonia: 167-75. Buenos Aires: INAPL-SAA.

Suby, J., F. Santiago \& M. Salemme. 2008. Análisis paleopatológico de los restos humanos del sitio Puesto Pescador 1 Tierra del Fuego. Magallania 361: 53-64.

Torres, J. 2009. Bolas líticas y sus procesos de manufactura, en contextos de cazadores recolectores terrestres del norte de Tierra del Fuego, evidencias desde el Holoceno medio hasta 1500 años AP, in M. Salemme, F Santiago, M Álvarez, E. Piana, M. Vázquez \& M.E. Mansur (ed.) Arqueología de Patagonia: una mirada desde el último confin: 381-400. Ushuaia: Editorial Utopías.

Received: 22 March 2010; Accepted: 6 July 2010; Revised: 16 May 2011

(C) Antiquity Publications Ltd. 